\title{
The Principle of Labour
}

There seems to be an ambivalence in Marx's presentation of commodity circulation in the beginning of Capital. On the one hand, circulation as presented in Capital is an 'outer surface' [Oberfläche] under which the production of commodities and of surplus value is hidden. It is, however, the necessary starting point of the analysis from which the more developed determinations are derived. ${ }^{1}$ The exchange of equivalents is the starting point of the transformation of money into capital:

The conversion of money into capital has to be explained on the basis of the laws that regulate the exchange of commodities, in such a way that the starting-point is the exchange of equivalents ... His development into a full-grown capitalist must take place, both within the sphere of circulation and without it. ${ }^{2}$

On the other hand, on several occasions Marx discussed the transformation of money into capital (and the development of commodity into money) as if he were describing a process of transformation from a historically preceding, simple exchange and circulation of commodities into a later, more developed one:

Production and circulation of commodities can take place, although the great mass of the objects produced are intended for the immediate requirements of their producers, are not turned into commodities, and consequently social production is not yet by a long way dominated in its length and breadth by exchange-value. The appearance of products as commodities pre-supposes such a development of the social division of labour, that the separation of use-value from exchange-value, a separation which first begins with barter, must already have been completed. But such a degree of development is common to many forms of society, which in other respects present the most varying historical features ...

1 Hochberger 1974, pp. 166-7.

2 Marx 1974-2004l, pp. 176-7. 
Yet we know by experience that a circulation of commodities relatively primitive, suffices for the production of all these forms. Otherwise with capital. $^{3}$

In Capital and the Grundrisse, Marx's critical intention was to prove that the appropriation of surplus value and the accumulation of capital is completely possible following the rules of commodity circulation; the development of capitalist production follows from simple circulation of commodities according to its own immanent laws. The law of appropriation of simple commodity production is transformed into the law of capitalist appropriation, but the very rules of exchange of commodities remain the same in capitalism too:

To say that the intervention of wage labour adulterates commodity production is to say that commodity production must not develop if it is to remain unadulterated. To the extent that commodity production, in accordance with its own inherent laws, undergoes a further development, into capitalist production, the property laws of commodity production must undergo a dialectical inversion so that they become laws of capitalist appropriation. ${ }^{4}$

By analogy, while discussing the transformation of the values of commodities into product prices, Marx similarly referred to a historically preceding, less developed exchange of commodities, which takes place directly according to values. Value is, then, both theoretically and historically the 'prius', the primary determinor, of the capitalist mode of production. In Marx's Capital, the capitalist commodity production was thus understood to have developed from a simple production of commodities characterised by the individual ownership of the means of production by every producer. In simple commodity production, appropriation of products was really based on one's own labour and only labour could create a right to private property:

The exchange of commodities at their values, or approximately at their values, thus requires a much lower stage than their exchange at their prices of production, which requires a definite level of capitalist development ... Apart from the domination of prices and price movement by the law of value, it is quite appropriate to regard the values of commodities as

3 Marx 1974-2004l, p. 180.

4 Marx 1990, pp. 733-4. 
not only theoretically but also historically prius to the prices of production. This applies to conditions in which the labourer owns his means of production, and this is the condition of the land-owning farmer living off his own labour and the craftsman, in the ancient as well as in the modern world. ${ }^{5}$

On the other hand, Marx was quite explicit in his statement that only after the introduction of the wage relation, and consequently the accumulation of capital, does the production of commodities become the general and dominating form of production: 'Only where wage labour is its basis does commodity production impose itself upon society as a whole; but it is also true that only there also does it unfold all its hidden potentialities.' ${ }^{6}$

It was Friedrich Engels who, in his interpretation of Marx's Capital, canonised the conception of 'simple commodity production'. In Anti-Dühring, simple commodity production is understood to be a specific mode of production preceding capitalism. ${ }^{7}$ This conception was preceded by the interpretation of the historical nature of Marx's presentation already in Engels's 1859 review of Marx's A Contribution to the Critique of Political Economy [Zur Kritik der politischen Ökonomie]. Marx's method was, according to Engels, basically historical: 'With this method we begin with the first and simplest relation which is historically, actually available, thus in this context with the first economic relation to be found. 8

The simple and historically first relation is that of two commodities in exchange. Political economy consequently takes the concept of a commodity as its starting point. The logical presentation and development of categories in Marx's work generally follows their actual historical development:

The point where this history begins must also be the starting point of the train of thought, and its further progress will be simply the reflection, in abstract and theoretically consistent form, of the historical course. Though the reflection is corrected, it is corrected in accordance with laws provided by the actual historical course, since each factor can be examined at the stage of development where it reaches its full maturity, its classical form. ${ }^{9}$

5 Marx 1974-2004l, pp. 175-6.

6 Marx 1990, p. 733.

7 Engels 1974-2004d, pp. 257-9.

8 Engels 1974-2004b, p. 225.

9 Ibid. 
The history of political economy [die literarischen Abspiegelungen], generally speaking, follows the development from the more simple to the more complex relations corresponding to the actual development of these relations. However, it must be freed and abstracted from many accidental turns in their development. In the logical presentation or analysis, these contingencies have been eliminated, and consequently the historical development is presented in its pure form. ${ }^{10}$

In his recension, Engels did not yet postulate the existence of simple commodity production as a historical stage of production preceding capitalism. He even stated that the analyses in the beginning of the treatise started from the commodity of a fully developed commodity exchange:

If we examine the various aspects of the commodity, that is of the fully evolved commodity and not as it at first slowly emerges in the spontaneous barter of two primitive communities, it presents itself to us from two angles, that of use-value and of exchange-value.11

Even though it is unclear as to whether Engels thought that a fully developed exchange of commodities was only possible after the wage relation had been introduced, his statement nevertheless problematised the historical interpretation. ${ }^{12}$ Engels's interpretation of the logical presentation as corresponding to the actual historical one was further and more strongly developed in his afterword and supplement to the 1895 edition of Capital..$^{13}$ Now Engels directly stated as a historical fact that there had existed a long period of commodity production in which exchange had taken place directly according to values and in which the means of production had belonged to the individual producers themselves. ${ }^{14}$ And Engels further claimed that Marx's theory of value was valid for the whole period of simple commodity production:

In a word: the Marxian law of value holds generally, as far as economic laws are valid at all, for the whole period of simple commodity produc-

\footnotetext{
$10 \quad$ Ibid.

11 Engels 1974-2004b, p. 226.

12 See also Backhaus 1981, p. 119.

13 Backhaus 1981, pp. 120-1.

14 'This makes clear, of course, why in the beginning of his first book Marx proceeds from the simple production of commodities as the historical premise, ultimately to arrive from this basis to capital - why he proceeds from the simple commodity instead of a logically and historically secondary form - from an already capitalistically modified commodity' (Engels 1974-2004g, p. 16).
} 
tion - that is, up to the time when the latter suffers a modification through the appearance of the capitalist form of production ... Thus, the Marxian law of value has general economic validity for a period lasting from the beginning of exchange, which transforms products into commodities, down to the $15^{\text {th }}$ century of the present era. ${ }^{15}$

The law of value is approximated as having governed the exchange of commodities for a period of around five- to seven-thousand years.

Engels's interpretation was made even more problematic by the fact that he seemed to think that the law of value resulted from conscious action on the part of the producers:

how then could they exchange these products of theirs for those of other laboring producers otherwise than in the ratio of labor expended on them? ... No other exchange is possible in the whole period of peasant natural economy than that in which the exchanged quantities of commodities tend to be measured more and more according to the amounts of labor embodied in them. ${ }^{16}$

And further:

People in the Middle Ages were thus able to check up with considerable accuracy on each other's production costs for raw material, auxiliary material, and labor-time - at least in respect of articles of daily general use. $^{17}$

Thus, in Engels's interpretation, the law of value would not be a law which, even though executed by the acts of exchange of individuals, still functioned blindly behind the backs of these individual actors; rather, it would simply be a method of counting the expenses of production. ${ }^{18}$

15 Engels 1974-2004h, p. 887.

16 Engels 1974-2004h, p. 885.

17 Ibid.

18 Backhaus ironically formulated what Engels seemed to think happened in the ancient society of fishermen and hunters. Fishermen and hunters could not supposedly exchange their products because the incommensurability of their use values excluded the possibility of exchange. One fine day, they were nevertheless lucky enough to get the idea of abstracting from the use value of their commodities and the concrete character of their labour. They found out that the property of being products of labour in general is the 
Marx's own self-understanding of his method and Engels's interpretation of it has been problematised by Hans-Georg Backhaus. ${ }^{19}$ Backhaus pointed out that Marx's method of presentation cannot be historical because a concept of a pre-monetary market economy cannot be constructed in a non-contradictory manner: 'The concept of a pre-monetary commodity should be recognised as a concept that is impossible to think of'.20

Marx's analysis of the value form should be understood essentially as a contribution to the theory of money. In his analysis of the value form, Marx criticised both Ricardo and Bailey. ${ }^{21}$ Ricardo, in studying only the quantitative determination of value, did not understand the relation of his labour theory of value to money. He did not pose the question as to why the contents must appear in a specific form or why labour presents itself as value. ${ }^{22}$ On the contrary, Bailey argued that money and value simply result from the actual relations of exchange, value is a contingent quantitative relation of two commodities - whereas Marx emphasised that, in reality, exchange is first constituted by value; the value of commodities is a necessary precondition for exchange. ${ }^{23}$ Backhaus's idea was that Marx's critique of Bailey in the third volume of Theories proved that Marx's presentation in the first chapters of Capital should be understood as a metacritique of Bailey's critique of Ricardo. ${ }^{24}$

Bailey's merit in relation to Ricardo was, according to Marx, that he abandoned the problem of the constant measure of value so essential to Ricardo's labour theory of value. ${ }^{25}$ Bailey was right in claiming that it is not necessary to suppose that the value of the commodity in which all other commodities are measured is a constant entity. Bailey did, however, deny that in order to be able to be exchanged, two commodities must have a common quality, which is different from their existence as useful objects, things:

necessary common property which makes it possible to exchange their commodities with each other - which had not succeeded earlier (see Backhaus 1981, p. 124).

19 Backhaus 1978; see also Backhaus 1974 and 1975.

$20 \quad$ Backhaus 1978, p. 38.

21 Backhaus 1981, p. 127.

22 Marx 1974-2004l, p. 35, n. 2.

23 Marx 1971, pp. 139-40.

24 Backhaus 1981, p. 13o. Rubin - whose work Backhaus did not refer to - had already presented a similar interpretation of Marx's critique of Bailey (see Rubin 1973, pp. 65-71). Rubin, however, did not in this context discuss Ricardo's faulty understanding of the money form, even though he otherwise seemed to come practically to the same conclusion concerning the role of money in Marx's reasoning (see Rubin 1973, p. 89). Neither did Rubin relate his discussion to the problem of the historical and logical character of Marx's presentation.

Marx 1971, pp. 133-4. 
Instead, he wanders off into all the categories of political economy in order to repeat the same monotonous litany over and over again, namely, that value is the exchange relation of commodities and consequently is not anything different from this relation. ${ }^{26}$

Bailey justified his argument by the observation that because the quantitative relations of commodities in exchange and consequently their money prices are not constant and vary from one act of exchange to another, the actual relation of two commodities in exchange determines their respective values. To Bailey, the concept of value was only a fictional and metaphysical entity wrongly deduced from the existence of money:

Only because, besides commodities, money exists, and we are so used to regarding the value of commodities not in their relation to one another but as a relation to a third, as a third relation distinct from the direct relation, is the concept of value evolved - and consequently value is transformed from the merely quantitative relation in which commodities are exchanged for one another into something independent of this relation (and this, he thinks, transforms the value of commodities into something absolute, into a scholastic entity existing in isolation from the commodities). According to Bailey, it is not the determination of the product as value which leads to the establishment of money and which expresses itself in money, but it is the existence of money which leads to the fiction of the concept of value. Historically it is quite correct that the search for value is at first based on money, the visible expression of commodities as value, and that consequently the search for the definition of value is (wrongly) represented as a search for a commodity of 'invariable value', or for a commodity which is an 'invariable measure of value'. Since Mr. Bailey now demonstrates that money as an external measure of value - and expression of value - has fulfilled its purpose, even though it has a variable value, he thinks he has done away with the question of the concept of value - which is not affected by the variability of the magnitudes of value of commodities - and that in fact it is no longer necessary to attribute any meaning at all to value. ${ }^{27}$

The problem of the determination of an objective value was shown by Bailey to be an unnecessary problem because the presentation of the value of a

\footnotetext{
26 Marx 1971, p. 140.

27 Marx 1971, p. 145.
} 
commodity in money does not exclude the possible change in the value of this commodity (money). ${ }^{28}$

However, the result of Marx's critique of Bailey was not just to show that in order to be exchanged, two commodities must have something in common, must be qualitatively similar and must be able to be measured on the same dimension. Marx also stated that Bailey was right in emphasising that the value of a commodity can only be expressed in its relation to another commodity or more correctly, it must present its value in that of another commodity, or more generally, they must both express their value in that of a third commodity, namely, money. This problem was totally neglected by Ricardo who, consequently, could not understand the relation of his theory of value to money. On the other hand, Ricardo was right as opposed to Bailey in understanding labour to be the immanent substance of value. ${ }^{29}$ Bailey did not pose the problem correctly because he did not analyse money as a qualitative 'transformation' of commodities, only as a quantitative one. ${ }^{30}$

According to Marx, Ricardo emphasised that labour is the common inner substance of value. Ricardo, however, neglected to study the specific form in which labour first becomes this substance of value:

All commodities can be reduced to labour as their common element. What Ricardo does not investigate is the specific form in which labour manifests itself as the common element of commodities. That is why he does not understand money. ${ }^{31}$

According to Marx, in order to be able to present themselves in money (' $M$ ', a third commodity), commodities must have a common qualitative property; their quantitative relation presupposes a common denominator:

A homogeneity which makes them the same - makes them values - which as values makes them qualitatively equal, is already presupposed in order that their value and their differences in value can be represented in this way. For example, if all commodities express their value in gold, then this expression in gold, their gold price, their equation with gold, is an

$28 \quad$ Marx 1971, pp. 145-6.

29 Cf. Marx: 'Our analysis has shown, that the form or expression of the value of a commodity originates in the nature of value, and not that value and its magnitude originate in the mode of their expression as exchange value' (Marx 1974-2004l, p. 71).

$30 \quad$ Marx 1971, pp. 13-8.

$31 \quad$ Marx 1971, p. 138. 
equation on the basis of which it is possible to elucidate and compute their value relation to one another, for they are now expressed as different quantities of gold and in this way the commodities are represented in their prices, as comparable magnitudes of the same common denominator. ${ }^{32}$

In order to be able to present their value in money, commodities must be identical in some respect:

Otherwise it would be impossible to solve the problem of expressing the value of each commodity in gold, if commodity and gold or any two commodities as values were not representations of the same substance, capable of being expressed in one another. ${ }^{33}$

The quantitative relations of commodities are determined by the quantity of simple or medium labour that has been used in producing them. But the labour forming the substance of value is not primarily simple or medium labour. Commodities are essentially products of private labour. As value, the commodity must, on the contrary, be a product of social or general labour. The whole problem can be formulated as the question of how private labour can present itself as its direct opposite, as social or general labour:

the labour of individuals has to be directly represented as its opposite, social labour; this transformed labour is, as its immediate opposite, abstract, general labour, which is therefore represented in a general equivalent, only by its alienation does individual labour manifest itself as its opposite. The commodity, however, must have this general expression before it is alienated. This necessity to express individual labour as general labour is equivalent to the necessity of expressing a commodity as money ... only through sale, through its real transformation into money, that the commodity acquires its adequate expression as exchange-value. The first transformation is merely a theoretical process, the second is a real one. ${ }^{34}$

Commodities are produced by private labour, which becomes social only through exchange, and their value must consequently be presented in a socially

$32 \quad$ Marx 1971, p. 134.

33 Ibid.

34 Marx 1971, p. 136. 
general form. And because private labour must be transformed into general, social labour, commodities must present their value in a specific commodity, money:

Because the product is not produced as an immediate object of consumption for the producers, but only as a bearer of value, as a claim, so to speak, to a certain quantity of all materialised social labour, all products as values are compelled to assume a form of existence distinct from their existence as use-values, and it is this development of the labour embodied in them as social labour, it is the development of their value, which determines the formation of money, the necessity for commodities to represent themselves in respect of one another as money - which means merely as independent forms of existence of exchange-value - and they can only do this by setting apart one commodity from the mass of commodities, and all of them measuring their values in the use-value of this excluded commodity, thereby directly transforming the labour embodied in this exclusive commodity into general, social labour. ${ }^{35}$

Backhaus's central conclusion was that the circulation of commodities as analysed by Marx in Capital is principally different from the simple exchange of commodities. The concept of a pre-monetary commodity is a contradictio in adjecto, and, consequently, it is impossible to think of an exchange process for pre-monetary commodities. ${ }^{36}$ Marx's theory of value should be understood as a critique of a pre-monetary theory of value. ${ }^{37}$ Marx was interested in developing an inner and necessary relation between value and money (the genesis of money form). ${ }^{38}$ When Marx asked the question why does this content appear in this form?, he also seemed to think that value cannot be thought of without its form of appearance. ${ }^{39}$ Value cannot be analysed correctly without its form of appearance, money, and money can only be understood as a form of appearance of an 'absolute' or objective value. Value does not exist without price and money.

Backhaus's interpretation is especially interesting because he discussed the possible reasons for Marx's attempt to justify his theoretical procedure in Capital as an ideal reflection of the real historical process of the development of

\footnotetext{
$35 \quad$ Marx 1971, pp. 14-5.

$36 \quad$ Backhaus 1981, p. 155 .

37 Backhaus 1981, p. 141.

38 Marx 1974-2004l, pp. 57-8.

39 Backhaus 1981, p. 128.
} 
money and capital. According to Backhaus, Marx - and even less Engels - did not seem to understand what he really was doing; Marx obviously felt unable to justify his categorial analysis and was therefore forced to take refuge in a pseudo-dialectical reasoning concerning the historical nature of his presentation. ${ }^{40}$

In Grundrisse, Marx explicitly stated that: 'This dialectical process of its becoming is only the ideal expression of the real movement through which capital comes into being. The later relations are to be regarded as developments coming out of this germ.41 It was Engels who suggested to Marx that results obtained dialectically should be justified historically in more detail. The evidence supporting Marx's theory should be taken from history. According to Engels, Marx already had enough material at his disposal to prove the necessity of the historical development of money. ${ }^{42}$

Backhaus argued that the material at Marx's disposal was, in fact, totally insufficient to prove any such hypothesis. Instead of being able to correct his 'idealistic manner' of reasoning materialistically, Marx adopted Aristotle's argument, which had also been adopted by Adam Smith. According to Smith, money was invented in order to surpass the problems of exchange brought about by an increasing division of labour. Money was invented to overcome the difficulties encountered in the exchange of commodities. ${ }^{43}$ Marx thought he had discovered a materialistic correction to his logical and seemingly idealistic development or deduction of categories - a task he had set out to undertake in Grundrisse:

It will be necessary later, before this question is dropped, to correct the idealist manner of the presentation, which makes it seem as if it were merely a matter of conceptual determinations and of the dialectic of these concepts. Above all in the case of the phrase: product (or activity) becomes commodity; commodity, exchange value; exchange value, money. ${ }^{44}$

$40 \quad$ Backhaus 1981, pp. 156-8.

41 Marx 1973, p. 310. In his introduction to Grundrisse, in which Marx explicitly reflected on his method of presentation, he clearly formulated an opposite thesis: 'It would therefore be unfeasible and wrong to let the economic categories follow one another in the same sequence as that in which they were historically decisive. Their sequence is determined, rather, by their relation to one another in modern bourgeois society, which is precisely the opposite of that which seems to be their natural order or which corresponds to historical development' (Marx 1973, p. 107).

42 Engels 1974-2004i, p. 381.

43 Backhaus 1981, pp. 157-8.

$44 \quad$ Marx 1973, p. 151. 
It was thus Marx's intended materialism that, according to Backhaus, was the main reason for his historical fables about simple commodity production and the historical development of money.

Marx, in fact, on several occasions referred to the necessity of introducing money because of the increasing division of labour and the increasing exchange of products, as if money had been invented in order to overcome the difficulties encountered in actual exchange of products in a period of history in which pre-monetary exchange of commodities had prevailed:

The further the division of labour develops the more does the product cease to be a medium of exchange. The necessity of a general medium of exchange arises, a medium independent of the specific production of each and every one. ${ }^{45}$

In Capital, the formulation of the same problem was more problematic. The existence of a general equivalent was seen to be necessary to any exchange between several commodities, but the introduction of money was still understood as a solution to the difficulties due to the increasing division of labour:

The necessity for a value-form grows with the increasing number and variety of the commodities exchanged. The problem and the means of solution arise simultaneously. Commodity-owners never equate their own commodities to those of others, and exchange them on a large scale, without different kinds of commodities belonging to different owners being exchangeable for, and equated as values to, one and the same special article. ${ }^{46}$

Backhaus saw the reason for Marx's insistence on the categorial presentation corresponding to actual historical development of the different forms of value as a desire to proceed materialistically and to correct his seemingly idealistic manner of presentation. One could, however, claim that there were other reasons for Marx's procedure, reasons that are closely connected with another essential interpretative argument of Backhaus. For Backhaus, Marx's 'labour theory of value' was a necessary consequence of his conception of an objective value: the idea of the necessary form of the appearance of value (money)

\footnotetext{
45 Marx 1973, p. 199. Cf. 'The money can overcome the difficulties inherent in barter only by generalizing them, making them universal' (Marx 1973, pp. 149-50).

46 Marx 1974-2004l, p. 99.
} 
could only be developed on the basis of an objective theory of value and, consequently, the labour theory of value. An objective or 'absolute' value can only be based on labour. ${ }^{47}$

It is not, however, at all clear why such an absolute value should be exclusively understood in this way. On the contrary, it could be claimed that such a position is highly problematic; and Marx's introduction of the concepts of abstract and concrete labour as producing use value and value, respectively, was rather straightforward, without any specific grounds. Stapelfeldt ${ }^{48}$ interestingly pointed out that Marx's introduction of abstract labour in his reasoning as the identical property of the commodities making possible their exchange is highly problematic. The definition was justified only through negation; according to Marx's reasoning, the common quality on which the identity of labour's products is based cannot be any substantial or natural quality of theirs, or their use value, because as use values commodities evidently are qualitatively different. The only possible identical quality of commodities after the abstraction or negation of their natural qualities or use values is their property as products of labour in general: 'If we then leave out of consideration the use value of commodities, they have only one common property left, that of being products of labour'49 Marx did not, however, give any further arguments in favour of the identification of the common quality found in the products of labour with labour in general. ${ }^{50}$

As Stapelfeldt pointed out, the difficulty in Marx's operation of abstraction culminates in its result. Marx abstracted from the determination of products as products of labour and once more got as the result - abstract human - labour: 'For Marx abstracts from the products of labour, but presents as a result the only thing remaining - abstract human labour. ${ }^{\prime}$

47 Backhaus 1981, p. 141.

48 Stapelfeldt 1979, p. 111.

49 Marx 1974-2004l, p. 48.

5o Marx's argument was, consequently, not convincing as such. It is easy to think of other common identical qualities of products in use. The price of commodities can be understood as being determined by their potential demand and supply, as was pointed out by Böhm-Bawerk in his classical critique of Marx's labour theory of value (see BöhmBawerk 1973 [1896]), which amounts to their determination by the marginal utilities. To take another extreme example, as was shown by Simmel (1900), one could also postulate a specific metaphysical sphere of values; or one could interpret value as a specific socially determined quality of commodities due to the social form of organisation of labour, as was the case in Rubin's theory of abstract labour and value (see Rubin 1973 [1924]).

$5^{1} \quad$ Stapelfeldt 1979, p. 115 . 
One further problem in Marx's procedure of abstraction is the definition of use value as a product of useful or concrete labour. In the beginning of his discussion of the dual character of a commodity, Marx defined use values simply as useful things which satisfy human needs. In discussing the dual nature of labour, Marx said that as such they are the product of useful activity: 'To resume, then: In the use value of each commodity there is contained useful labour, i.e., productive activity of a definite kind and exercised with a definite aim'. 52

According to Stapelfeldt, Marx needed a more determined definition of use value, or a definition of the identical quality of use values for his further argument. ${ }^{53}$ Use values are not simply useful things. Use values are also products of labour, of a specific productive or useful activity:

So far therefore as labour is a creator of use value, as useful labour, it is a necessary condition, independent of all forms of society, for the existence of the human race; it is an eternal nature-imposed necessity, without which there can be no material exchanges between man and Nature, and therefore no life. ${ }^{54}$

In Stapelfeldt's opinion, Marx's procedure of abstraction was only legitimate because of the presupposed truth imbedded in classical political economy. Marx's analysis of a commodity is only understandable when it is understood that it takes place within this tradition of thought, which becomes evident during the problematised argumentation of abstract labour as determining the common quality of commodities. Marx's dual reference to labour makes his close relation to natural rights theory and classical political economy evident. ${ }^{55}$ Marx did not, however, only adopt the concept of labour from classical political economy. He also criticised it for its ambivalence. In Marx's opinion, classical political economy lacked the understanding of the dual nature of labour. In classical political economy, the concept of labour referred both to humanity's relation to nature and to the intersubjectivity of social relations, and remains thus undifferentiated. After the introduction of the dual concept of labour, the different use values and concrete products of labour can, on the one hand, be regarded as equal because abstract labour has been objectified in them. Their comparability is based on abstract labour. On the other hand, the concrete

\footnotetext{
$5^{2} \quad$ Marx 1974-2004l, p. 52.

53 Stapelfeldt 1979, p. 115 .

54 Marx 1974-2004l, p. $5^{2}$.

55 Stapelfeldt 1979, p. 117.
} 
labour producing use values is closely tied to nature's substance and is in every case as different as its products. They cannot thus be considered as identical to one another. In order to emphasise the contrast, Marx named the equal substance of commodities as 'abstract human labour', and understood it to be a result of abstraction. But abstract labour can, on the other hand, only be the common quality of commodities because labour is, in fact, materialised in use values; they are in some strong sense products of labour. Classical political economy never understood this difference in its concept of labour and was criticised by Marx accordingly. ${ }^{56}$

It is essential, however, that the concept of value shares with that of 'concrete labour' the idea that labour has in reality been objectified and materialised in its products. ${ }^{57}$ The reproduction of social relations thus takes place within the production of use values - the value has concrete labour as its necessary precondition - which in Stapelfeldt's opinion determines Marx's doctrine as both materialistic and dialectical:

The critique of political economy is materialist because it shows that value is the abstraction from man's relationship to nature, that the existence of value is therefore conditioned by concrete labour and that the products of labour are reduced to its form of appearance. This materialism is dialectical because it formulates the experience of a bifurcation of society's and man's relationship to nature, of abstract and concrete labour ... The doctrine of the double-character of the labour embodied in commidities defines the critique of political economy as a dialectical theory. 58

As Stapelfeldt has pointed out, Marx's critique of the concept of labour was only convincing because of its close conceptual relation to classical political economy. It adopted its standards of critique from the latter:

The critique of political economy is only able to be constituted by attaching itself to the false aporia of classical political economy, by proving to solve political economy's thoroughgoing rupture of concrete and abstract labour in all relevant specifications and thereby gaining both the experiential basis of the criticised as well as the critic's own benchmark of critique. $^{59}$

$56 \quad$ Stapelfeldt 1979, pp. 121-2.

57 Stapelfeldt 1979, pp. 133-4.

$5^{8} \quad$ Stapelfeldt 1979, p. 224.

59 Stapelfeldt 1979, pp. 251-2. 
The critique was directed against both the capitalist mode of production and its scientific expression. It aimed at destroying the claim of reason of bourgeois society, the concept of reasonable society, which projects the social relations into natural relations, into humankind's relations to nature. ${ }^{60}$

Marx did not, however, only redefine the concept of labour by introducing his conception of the dual character of labour. He also redefined the concept of labour in another sense, and in so doing radicalised the critical potency of his analysis. It was essential to Marx that through labour the very goaloriented activity of a person is materialised in its products and objectified in the social relations too. According to Lange, ${ }^{61}$ this conceptual redefinition of labour already took place in the Economic and Philosophical Manuscripts of 1844, in which Marx discovered labour to be the real principle of national economy:

The fact expresses merely that the object which the labour produces labour's product - confronts it as something alien, as a power independent of the producer. The product of labour which has been embodied in an object, which has become material; it is the objectification of labour. ${ }^{62}$

In Marx's manuscript, objectification [Vergegenständlichung] became synonymous with becoming a material object. Labour is, then, materialised very concretely in the products of labour. ${ }^{63}$ Marx's conceptual operation made it possible for him to radicalise the concept of labour into a model of objectification or alienation and use it as a critical model. ${ }^{64}$ The concept of objectification of labour made it possible to understand and to criticise the national economic state of affairs [nationalökonomischer Zustand] or bourgeois society, and the process of private property. Private property and the relations of bourgeois society are reduced to the worker's alienated self-relation to himself and to his alienated relation to the products of his own labour (the product of his labour, his very labour process, and the essence of human species [Gattungswesen] all become alienated). The very opposition of classes in a bourgeois society is based on the missing self- and object relation of the worker ${ }^{65}$

The same idea of materialisation and objectification of labour was also strongly present in Capital: 'A use value, or useful article, therefore, has value

\footnotetext{
6o Stapelfeldt 1979, pp. 64-5.

$61 \quad$ Lange 1980, p. 55.

62 Marx 1974-2004b, p. 272.

63 Lange 1980, p. 56.

64 Lange 1980, pp. 68-9.

65 Lange 1980, pp. 81-2.
} 
only because human labour in the abstract has been embodied or materialised in it'.66 By analogy, the use value of a commodity represents materialised labour. The main difference of Marx's later critique of political economy in relation to the manuscript of 1844 was that labour was no longer understood to be the real principle of the bourgeois society. According to Marx, it was now wrong to say that capital is just the result of accumulated labour. In the Grundrisse, for instance, Marx claimed that the characterisation of capital as accumulated labour in no way described capital specifically, but in fact described any instrument of production. ${ }^{67}$

Lange, however, claimed that while beginning the presentation of Capital with commodity and money, Marx was, in fact, still indirectly beginning it with the category of labour. Labour did not then become the very principle of national economy, but its contradictory principle:

As such, labour itself is a contradiction to be unveiled, the fundamental contradiction, even, on which the contradiction of labour and capital and class-antagonisms are then based. Labour cannot therefore be the point of departure of the presentation unveiling the ever more fundamental contradictions that destroy illusory unities, despite labour itself being, in an estranged way, 'by itself' or 'for us' - the theoretical observers - a principle. ${ }^{68}$

In Capital, Marx did not begin his analysis with the concept of labour, or with alienated labour, but with the concept of commodity. Labour, then, is conceptually redefined; labour producing commodities has a dual character. Labour is no longer - as it was in Ökonomisch-philosophische Manuskripte - the fundamental principle of the national economy, from which all further consequences ensue, but rather a principle of a contradictory nature. Despite this self-critique and conceptual redefinition, Marx was, however, strongly indebted to classical political economy and its predecessor, the natural law theory. It was the concept of labour and the labour theory of value which Marx interpreted to be the rational core of classical political economy. And certain important elements of it can already be found in natural rights thinking. Classical thinking does, however, result in anomalies as reconstructed by Marx, because of its misunderstanding of the dual character of labour and the specific historical

\footnotetext{
66 Marx 1974-2004l, p. 48.

67 Marx 1973, pp. 85-6; see also Lange 1980, p. 146.

68 Lange 1980, p. 150.
} 
and social form of labour in a society ruled by commodity exchange. But still one can agree with Schanz ${ }^{69}$ - and Lange - in interpreting labour as the most important concept in Marx's Capital too.

As has already been pointed out, Marx's argument included another important conceptual redefinition of the concept of labour, which was not present in classical political economy or natural rights theory. Marx understood labour to be materialised and objectified in its products, in commodities. For instance, it was essential for Marx to emphasise that abstract labour could only be objectified in the material products of labour. In discussing his value form analysis, Marx stated that human labour power is always objectified in a specific form, in the product of specific concrete labour:

Human labour, plain and simple, the expenditure of human labour power, may be capable of any determination, but in and of itself undetermined. It can only be realised, only objectified, when human labour-power is expended in a specific form, as specific labour, for only specific labour is confronted with a natural substance, an external material, within which it is objectified. ${ }^{70}$

Marx was ridiculing Hegelian concepts, which can objectify themselves without any external substance: 'Only the Hegelian "concept" is capable of objectifying itself without external material. ${ }^{71}$

From his conception of objectification it also follows that the value of a commodity can only appear in the use value of another commodity; in Marx's opinion, value must appear and it can only come into appearance in the relation of two commodities. As stated by Marx, one peculiarity of the value form is that use value becomes the form of appearance of its direct opposite, value, or to put it in another way, concrete labour becomes the form of appearance of its opposite, abstract labour. ${ }^{72}$ In another context, Marx wrote that it is wrong to say that labour is the sole source of riches. Nature is equally a source of use value, the universal substantial form of riches: 'Labour is not the source of all wealth. Nature is just as much the source of use values (and it is surely of such that material wealth consists!) as labour, which itself is only the manifestation of a force of nature, human labour power. ${ }^{73}$ Marx furthermore added that

\footnotetext{
69 Schanz 1981, p. 260.

$70 \quad$ Marx 1867, p. 18.

71 Ibid.

72 Marx 1974-2004l, pp. 67, 69.

73 Marx 1974-2004f, p. 81. In Capital, Marx approvingly paraphrased William Petty: 'Labour is the father (of material wealth) and the earth is its mother' (Marx 1974-2004l, p. 5).
} 
only insofar as humankind relates itself to nature as its owner and treats it as belonging to it, does human labour become the source of use values and consequently of riches. It is only because people cannot objectify their labour without the necessary means and objects of production originally created by nature that private property and capital, too, are possible at all. Otherwise any person possessing her or his own labour power exclusively could work and support themselves without the consent of the person owning and controlling the instruments of labour and the necessary resources of nature. ${ }^{74}$

Taking into account Marx's redefinition of labour and discussion of the concept of labour, it becomes possible to explicate his critique of private property and the form of capitalist appropriation. Marx's critique was twofold: It is not humanity's relation to nature via labour that constitutes private property. Private property is not based on a person's right to appropriate the products of his own labour. Private property furthermore has the exchange of commodities as its necessary precondition. It is first established in a society where private labour is transformed into social labour through exchange of commodities. But it was equally important for Marx to understand that commodities are appropriated from nature by materialising labour in them, and the materialisation of labour is not possible without the corresponding potentialities of nature. Marx then not only criticised what, in his understanding, was the fundamental legal conception of private property in classical political economy. He also adopted and - by redefining the concept of labour - radicalised its central insight. In capitalism, private property is not based on labour; in fact, the products of alien labour are approriated by capitalists without an equivalent. And in general, it is never labour - the productive relation of a human being to nature that constitutes private property. Legal and political ideas are only reflexions or expressions of more fundamental social relations of production. Still, even for Marx - and even in capitalism - products are originally appropriated from nature by labour. It is the labour power, the productive activity of the worker, that is materialised in commodities, and in the material elements of riches in general.

As has already been pointed out, Backhaus claimed that it was Marx's intended materialism that made him attempt to justify his value form analysis as corresponding to an actual historical development from less developed forms of value into more developed ones. Considering the previous discussion of Marx's concept of labour, one can, however, go even further and claim that it was Marx's labour theory of value - recognised by Backhaus as the only alternative 
to determine an objective value - that is to be blamed. The same problem can also be formulated as follows: because of his labour theory of value, Marx in fact did analyse the production of commodities before circulation and exchange of commodities. At the beginning of Capital, Marx analyses not only the simple circulation of commodities, but also the simple production of commodities.

Rubin $^{75}$ recognised that there is a seeming ambivalence in Marx's reasoning at this point: on the one hand, value and abstract labour were already presupposed before the exchange of commodities could take place, and on the other hand, value was first constituted in the very process of exchange. ${ }^{76}$ The same duality of reasoning can also be formulated in Rubin's own words as follows:

By showing that there can be no value-form without value, at the same time Marx precisely demonstrated that this social form will remain empty without the substance of labour [Arbeitssubstanz] that fulfils it. ${ }^{77}$

Rubin solved the problem by assuming that in production oriented towards a market, the very production process already has a specific social form: it is

75 Rubin 1973, p. 110.

76 Sohn-Rethel's critical interpretation of Marx's analysis of the forms of value pointed out the same ambivalence as Rubin's. Sohn-Rethel went even further and suggested that Marx's analysis at the beginning of Capital is inconsistent because Marx does not clearly distinguish between the problems of the magnitude and the form of value (see SohnRethel 1978, p. 21; see also Sohn-Rethel 1972, p. 235). Inspired by Sohn-Rethel's interpretation, Pietilä proposed an original solution to the problem of the relation between the 'historical and logical' in Marx's analysis of the form of value corresponding to the quantitative and qualitative aspects pointed out by Sohn-Rethel (Pietilä 1984). The first level consists of 'a "logical" theory aiming to show that money is nothing but "the necessary form of expression of the immanent value measure of commodities, viz. the labour time"' (Pietilä 1984, p. 63). 'The second level, in turn, would indicate the historical development of the structure of exchange relations and the necessities of this structure - precisely in the premonetary era' (Pietilä 1984, p. 64). Pietilä's interpretation is problematic because there is hardly any analysis of the development of the structure of exchange relations in Capital except of the exchange of commodities. The form of value analysed by Marx is always the form of value of a commodity; the use value of a commodity becomes the form of appearance of the value of another commodity. And consequently, the quantitative and form aspects are closely intertwined in Marx's argumentation. Therefore Marx's presentation can hardly be read as both an analysis of primitive (pre-monetary) exchange of products and an analysis of a developed exchange of commodities, respectively. As will be shown in the present study, it is exactly - to use Sohn-Rethel's expression - the 'quantitative' aspect of value in Marx's reasoning that explains his historicising intention. 
labelled by exchange from the very beginning. ${ }^{78}$ Production and circulation of commodities thus are mutually conditioned. But Rubin's argument did not really solve the problem; it only reformulated it. The same ambivalence is also present in Marx's twofold critique of both Ricardo and Bailey, a critique discussed both by Backhaus in the context of the logical and historical presentation in Marx's Capital, and in the present context by Rubin himself. ${ }^{79}$ As was already pointed out in Marx's reconstruction of the history of political economy, Bailey and Ricardo were made to criticise one another. Ricardo's fault, then, was that he neglected to analyse the specific form of labour, the value form which first constitutes value. Ricardo, in Marx's opinion, however, correctly identified the substance of value with labour. The other debater, Bailey, did not admit that exchange presupposes that commodities have an objective value, a common quality making their exchange possible, and consequently he dismissed the whole concept of value as a metaphysical entity not needeed by political economy. But Bailey's theory too had its own merits. He correctly recognised that the value of a commodity can only appear in its relation to another commodity. Thus, both Bailey and Ricardo provided certain invaluable insights adopted by Marx in his analysis of value and value form.

The importance of Marx's critique of Ricardo received special emphasis in Backhaus's analysis. For the present argument, Marx's critique of Bailey is more important. In rejecting value as an unnecessary entity for the analysis of the exchange of commodities, Bailey failed to understand that in order to be exchanged, two commodities must already possess a common qualitative property making their exchange possible. And like Ricardo, Marx identified this common quality with value, and the substance of value with labour. Without being an independent item in Marx's analysis - value admittedly was always thought to be connected with its value form, as pointed out by Rubin ${ }^{80}$ - the elements of a labour theory of value were indispensable to Marx's theory. They can be said to form the Ricardian - and Smithian - heritage in Marx's thinking. They can also be said to constitute Marx's Marxism.

It can now be claimed that by identifying value with a specific social form of labour, and by identifying the substance of value with labour, Marx opened up his argumentation to a historical interpretation of the development of value forms. It was thus Marx's labour theory of value that led him to present those 'pseudodialectical fables' referred to by Backhaus. ${ }^{81}$ Because of the labour the-

$78 \quad$ Rubin 1973, p. 112.

79 Rubin 1973, p. 72.

$80 \quad$ Rubin 1973, pp. 81-2.

81 This does not mean that Backhaus's suggestion of Marx's intended materialism as the 
ory of value it becomes reasonable to assume that any commodity exchanged for another already has a value, a common quality making the exchange possible, and that any two products in exchange inevitably are exchanged according to their value, since labour already has been objectified in them. On the other hand, Marx evidently thought that products of labour have a commodity form only insofar as they are produced in order to be exchanged, only insofar as they are produced for a commodity market, that is to say, only insofar as the commodity form has become the general form of the products of labour. ${ }^{82} \mathrm{But}$ if it is admitted that the value of a commodity also preceeds its exchange, if commodities have a value only insofar as labour has in fact been objectified in them, then it is resonable for Marx to think that the less developed value forms really are independent forms historically preceding the forms of money and capital. Consequently, even a less developed exchange of commodities inevitably follows the rule of equal exchange.

The element of a labour theory of value in Marx's reasoning similarly explains why, on several occasions, while discussing the transformation of the forms of appropriation, he seemed to think that there had, in fact, existed before and alongside capitalism a form of commodity production characterised by the private ownership of the means of production by every individual producer. Even though he explicitly criticised classical political economy for its postulate of a natural society (identified with bourgeois society) - a natural state in which labour's products belonged to the very man who had produced them by his own labour and in which private property was constituted by appropriating nature's products by labour - one could still claim that he came very close to postulating such a society himself.

One could, like Lange, ${ }^{83}$ rescue Marx by saying that he assumed the existence of simple commodity production only counterfactually. But Marx did not proceed counterfactually. He did not simply say that even if we were to suppose - following classical political economy and John Locke - that there once

reason leading to his 'pseudodialectical fables' should be totally rejected either. Marx obviously thought that the categories developed by him were 'real' abstractions in the sense that they corresponded to a state of affairs that had existed in its pure form in history; in capitalism, value appears only in different modified forms, hence it must have appeared in its pure form at some previous historical stage.

82 Cf. Marx's compact formulation in Capital: 'Quite the contrary: whenever, by an exchange, we equate as values our different products, by that very act, we also equate, as human labour, the different kinds of labour expended upon them. We are not aware of this, nevertheless we do it' (Marx 1974-2004l, pp. 84-5).

83 Lange 1980, pp. $175^{-6}$. 
existed a natural society in which nature's products were exclusively appropriated and a legitimate title to property created either by one's own labour or by exchanging the products of one's own labour with the products of other men's equal amount of labour, and even if we were, in addition, to suppose that the law of value is preserved intact even in capitalism, the truth about capitalism still is that alien labour and its products are in fact appropriated and that one has to respect one's labour and its products as belonging to another. Marx's postulate was a stronger one, as he explicitly stated that if commodities are produced by individual producers owning their own means of production, then their exchange takes place directly according to their value and one can achieve a title to property only by one's own labour. And he furthermore claimed that such simple commodity production had existed at various times and in various places in history.

One could also summarise the result of the above analysis as follows: the analysis of the simple circulation of commodities in Capital does not only consist of an abstraction of certain aspects of capitalist circulation of commodities. It is not an abstraction which must be taken as the starting point for the development of the theoretical presentation because it determines the specific social and historical character of the capitalist society as interpreted by Rubin. ${ }^{84}$ Via the labour theory of value and the specific radicalisation of the concept of labour, the production of commodities is introduced into the analysis from the very beginning. Labour has, in fact, been materialised and objectified in a commodity, otherwise it would not possess the dual character of use value and value. In discussing the opposite laws of appropriation in simple commodity production and in capitalism, respectively, or the equality and freedom of the commodity owners and exchangers, Marx only added one more condition or characteristic to his determination of simple circulation. Simple commodity production then is a specific form of production having its own social conditions; it is equal to simple circulation of commodities plus the private ownership of the means of production by every individual producer.

In his Critique of the Gotha Programme, one of his last writings, Marx formulated in a condensed form his critical standpoint, which clearly showed that he had not departed so far from the theoretical standpoint of classical political economy by turning its standards of natural society into critical standards of bourgeois society. Marx agreed on the formulation of the programme that in any imaginable society labour always is the real source of riches, and anyone not working himself can only be living at the cost of the labour of others:

84 Rubin 1973, pp. 43-9. 
Since labour is the source of all wealth, no one in society can appropriate wealth except as the product of labour. Therefore, if he himself does not work, he lives by the labour of others and also acquires his culture at the expense of the labour of others. ${ }^{85}$

From this formulation it is but a short step to understanding the central contradiction of capitalism in terms of the violation of the original rule of appropriation valid in simple commodity production. ${ }^{86}$ Thus it is not surprising that Marx obviously approved of and even contributed to Engels's interpretation of the fundamental critical result of his theory of capitalism as presented in AntiDühring. The way Engels - and Kautsky - put it, there is a basic contradiction in capitalism between the private mode of appropriation inherited from the stage of simple commodity production and the increasing socialisation of production. Marx in fact never formulated his own standpoint in quite the same terms, but if one understands Engels's contradiction as a shorthand formulation of the thesis that even in capitalism it is the labour power or, more specifically, the combined power of wage workers united in the production process by capital, that, in the last instance, is the source of value and riches, Marx would probably recognise it as his own.

$85 \quad$ Marx 1974-2004f, p. 82.

86 There is, however, one important difference between Marx's and Engels's ideas, respectively. Marx obviously did not think that simple commodity production equaled a specific mode of production of its own as Engels and later Marxists, Kautsky among them, were inclined to do. Marx simply thought that simple commodity production had taken place at different times and in different places alongside different modes of production, and that simple commodity production can take place alongside capitalism too. The relation between simple commodity production and capitalism was not understood by Marx as a process of historical transformation leading from one mode of production to another followed by the increasing socialisation of production. All that Marx suggested was that simple commodity production is an independent form of production - and that the different value forms are historically independent forms of value too - having a reality of its own. 